UDC 331.1: 378.091 .39

\title{
BUSINESS GAMES FOR LABOR SAFETY AS EFFECTIVE INSTRUMENT FOR IMPROVING WORKPLACE KNOWLEDGE OF FUTURE AGRICULTURAL ENGINEERS
}

\author{
O. V. Voinalovych, S. M. Holopura
}

National University of Life and Environmental Sciences of Ukraine, Ukraine.

Article from specialty 133 - industry engineering.

Corresponding authors: voynalov@bigmir.net.

Article history: Received: March 2019. Received in the revised form: April 2019. Accepted: August 2019.

Bibl. 13, fig. 2, tabl. 1.

Abstract. The article is devoted to the theoretical and practical analysis of the use of the business game method for professional training of agricultural engineers. It is noted that the problem of using the game in the system of socio-pedagogical work is widely represented in terms of pedagogy in general research. At the same time, we see a shortage of domestic research devoted to the development of theoretical foundations and to improve the practice of using business games as an active method of training future agricultural engineers. The specificity of game activity is defined, which is in the direction of preventive, preventive orientation of the game as a method of organizing meaningful training of future specialists.

The purpose of the research is to develop, scientifically substantiate and experimentally test the methodology of business game "Organization of performance appraisal on working conditions at the enterprise", aimed at familiarizing students with the procedure of assessing the degree of harm in the workplace of agricultural production. The result of such games can be both the direct development of personality traits and the demonstration of practical training of agricultural research engineers. Playing certain situations, involving the participants of the game in a situation of choice is a real way of developing a creative personality, namely its qualities such as creative interest, inquisitiveness, desire to know yourself, selfconfidence, creative optimism.

In this paper, the degree of mastering of educational material by students after conducting practical lessons in the form of the business game is analyzed in comparison with students of control groups, in which this topic was presented in a lecture form. The form of student evaluation was to answer the test tasks and descriptive questions of the module. The average scores of the 100-point system responses were compared with the results of the controls in the control groups, taking into account the overall score of the groups in the academic year.

Key words: business game, occupational safety and health, job attestation on working conditions, production situation, degree of mastering of educational material.

\section{Introduction}

Studying the disciplines of the complex "Occupational Safety and Health (Professional Safety)" is aimed not only at introducing students to the scientific and practical foundations of these disciplines, but also at mastering future specialists of a high level of knowledge and skills in the field of occupational safety, ie assimilation of occupational safety culture. This can be achieved through the formation of the student's personality, who will ensure compliance with occupational safety and health standards at work, guided by the current occupational safety normative documents, able to develop and implement them. A rationally organized system of training in the study of vocational disciplines should be the basis and one of the determining factors for the formation of the personality of the modern manager of agro-industrial production.

\section{Formulation of problem}

The urgency of writing the article is due to the evergrowing need to find new, scientifically substantiated, practically meaningful and methodologically expedient ways of successful training of agricultural engineers [1] during the study of the discipline "Occupational Safety and Health". Together with modern teaching methods (explanatory-illustrative, sign-contextual, case method, etc.), game methods [2] are very effective approaches to the study of innovative technologies in the training of specialists [3], allowing for a flexible, conscious, successful person-parties, able to think outside the box, to solve urgent questions and to predict the future activity of the enterprise.

Educational business games are such methods (forms) of learning in which they model certain aspects of production activity, which are accompanied by problematic situations $[4,5]$, which should help students to acquire organizational skills in the field of occupational safety. Solution of possible problems (problems) at the stages of development develops in students creative and practical thinking, forms the ability to analyze the consequences and circumstances of production activities, and 
on their basis to make informed recommendations. Educational business game encourages students to independently search for solutions to production problems, simulates situations of practical use of the obtained theoretical knowledge, and forms the skills of working in the workforce.

\section{Analysis of recent research results}

Well-known scientists were engaged in the development of game forms and methods of using the game in the professional training of future specialists: L. Vygotsky, B. Likh-chov, A. Verbitsky, A. Livshits, T. Khlebnikova, G. Se-levko, E. Khrutsky et al. [6 - 8]. In the works of L. Vygotsky, V. Platov, D. Elkonin it is argued that the business game is a pedagogical tool and an active form of learning, which shapes educational activity and develops professional skills [9]. G. Ab-Ramova, V. Stepanovich, I. Kuleshov emphasize that business play is an important condition for stimulating interest in knowledge [9], a method of active learning that contributes to the achievement of specific tasks, structuring the system of business relationships of participants.

Its structural elements are the designing of reality, the conflict of the situation, the activity of the participants, the appropriate psychological climate, interpersonal and intergroup communication, the solution of problems formulated at the beginning of the game, which as a result creates conditions for improving the effectiveness of the educational process.

Based on the analysis of numerous publications [4 9] we can conclude that the production activity of the modern manager is characterized by the ability to independently obtain the necessary information, quickly navigate in non-standard situations, constantly improve the level of their professional knowledge. A prerequisite for the selective character of cognitive activity is the focus of future research engineers on agricultural mechanization on objects of cognition. [1].

Therefore, higher education can not meet modern requirements, if the educational process does not pay attention to students' acquisition of the system of skills and skills, through their own experience, search and understanding [1].

The amount of information in the field of occupational safety and health is changing so fast that it is impossible to summarize it at lectures and completely absorb it [12].

The most effective form of practical training of students in occupational safety disciplines is a business game - which helps to supplement and consolidate the knowledge acquired during the study of the theoretical course of occupational safety, to enhance the creativity of students, to develop skills in working with regulatory legal acts. work and with reference literature, learn how to independently solve labor protection issues in project documentation, gain experience in performing engineering calculations based on labor protection documents (to be used on Ali diploma in design and in the future in theNairn in the field), to prepare for self-ment develop measures to create a safe and friendly working environment in all sectors of the production [10 - 13].

\section{Purpose of research}

Develop and implement a business game "Organization of performance appraisal of workplaces at the enterprise", aimed at familiarizing students with the procedure of assessing the degree of harm in the workplace of agricultural production.

\section{Results of research}

The studies were conducted among students of the Faculty of Mechanical and Technological Faculty of NULES of Ukraine in Kyiv. where classes were conducted in the form of a business game. The degree of mastering the learning material by the students on the 100-point system in the study and control groups was analyzed (tab. 1).

Table 1. Results of the conducted assessment of students' knowledge on the topic "Organization of workplace certification under working conditions at the enterprise" and the average score of groups for the academic year, in the control and research groups.

\begin{tabular}{|c|c|c|c|c|c|}
\hline \multicolumn{3}{|c|}{ Control groups } & \multicolumn{3}{|c|}{ Study groups } \\
\hline group & group & group & group & group & group \\
\hline 1 & 2 & 3 & 4 & 5 & 6 \\
\hline 74 & 60 & 74 & 91 & 86 & 80 \\
\hline 88 & 74 & 90 & 88 & 95 & 82 \\
\hline 68 & 77 & 82 & 74 & 79 & 74 \\
\hline 64 & 68 & 74 & 68 & 89 & 68 \\
\hline 74 & 78 & 60 & 75 & 78 & 85 \\
\hline 86 & 82 & 70 & 89 & 92 & 90 \\
\hline 90 & 74 & 74 & 92 & 74 & 82 \\
\hline 60 & 76 & 80 & 74 & 83 & 74 \\
\hline 68 & 70 & 79 & 74 & 84 & 77 \\
\hline 76 & 75 & 90 & 93 & 75 & 80 \\
\hline 61 & 74 & 75 & 90 & 87 & 75 \\
\hline 91 & 60 & 62 & 92 & 76 & 68 \\
\hline 80 & 75 & 74 & 84 & 90 & 90 \\
\hline 76 & 90 & 76 & 74 & 60 & \\
\hline 80 & 60 & 65 & 90 & 74 & \\
\hline 76 & 74 & 65 & 80 & 82 & \\
\hline 74 & 74 & 74 & 70 & 93 & \\
\hline 75 & 60 & 70 & 92 & 74 & \\
\hline 74 & 60 & 60 & & 73 & \\
\hline \multirow{5}{*}{60} & 82 & & & 64 & \\
\hline & 74 & & & 71 & \\
\hline & 82 & & & 60 & \\
\hline & & & & 67 & \\
\hline & & & & 74 & \\
\hline \multicolumn{6}{|c|}{ The average values of the control module } \\
\hline 71,9 & 72,68 & 73,36 & 77,95 & 78,33 & 78,84 \\
\hline \multicolumn{6}{|c|}{ Average performance values } \\
\hline 81 & 73,65 & 75,25 & 78 & 73,15 & 75 \\
\hline
\end{tabular}

As noted above, the distinctive feature of a business game is the presence of a simulation model. The structure of a business game involves the following main stages: preparation, conducting the game, analyzing and generalizing its results. Development begins with defining the 
purpose and objectives of the game, formulating requirements for participants in the business game. The purpose of the game has two aspects: motivational and didactic.

Here is a procedure for conducting a business game that was conducted with students - future agro-engineers. After acquaintance with the methodical recommendations-we on performance appraisal of workplaces (according to the decree of the Cabinet of Ministers of Ukraine of August 1, $1992 \mathrm{~N} 442$ ) and the description of production conditions (according to the appendix" Input data of business game") From the students are formed attestation commissions, the participants determine the duties, functions and rights of each member of the commission. Each group is provided by LAOS 0.00-6.23-92 "On the procedure of attestation of workplaces under working conditions", methodical instructions for measuring the parameters of production environment and forms. In particular, this is a form of the task for the execution of the game, the form of Maps of working conditions, the classification parameter of the parameters of the production environment, as well as instruments: a multifunctional meter of the parameters of the production environment and universal gas analyzer.

Participants of the game should outline a plan for performance appraisal of workplaces based on working conditions, taking into account the plans of equipment placement, define boundaries of workplaces (work zones), make a list of workplaces subject to appraisal. The Commission shall determine the volume of studies of harmful and hazardous environmental factors and shall organize those studies. Participants of the game write from the
Occupational safety and health documents (directories) normative (permissible, optimal) values of the parameters of the industrial environment, which correspond to the place and time of performance appraisal of workplaces.

Subgroups of students make up for each accountingnot workplace or group of similar places of the Working Conditions Map in accordance with the protocols of research of production factors, by means of the classifier establish the degree of exceedance of the measured parameters relative to the normative ones. The number of environmental factors exceeding regulatory values is calculated. Determine to what class and level the conditions and nature of work in the given workplace (of the specified profession) belong. They formulate recommendations for improving working conditions, their economic justification, as well as proposals for establishing benefits and compensations for working in hazardous and dangerous conditions.

The results of the performance appraisal depend on whether employees will receive benefits and compensation for long-term working conditions in accordance with labour-law legislation. Often, the problem is that management does not want to be certified due to its high cost and the need to improve working conditions, eliminating (reducing the impact) of harmful production factors.

Checking the effectiveness of the implementation of the new teaching methodology for the assimilation of the material was due to the preparation of reports on the work performed and demonstration of presentations of the obtained results.

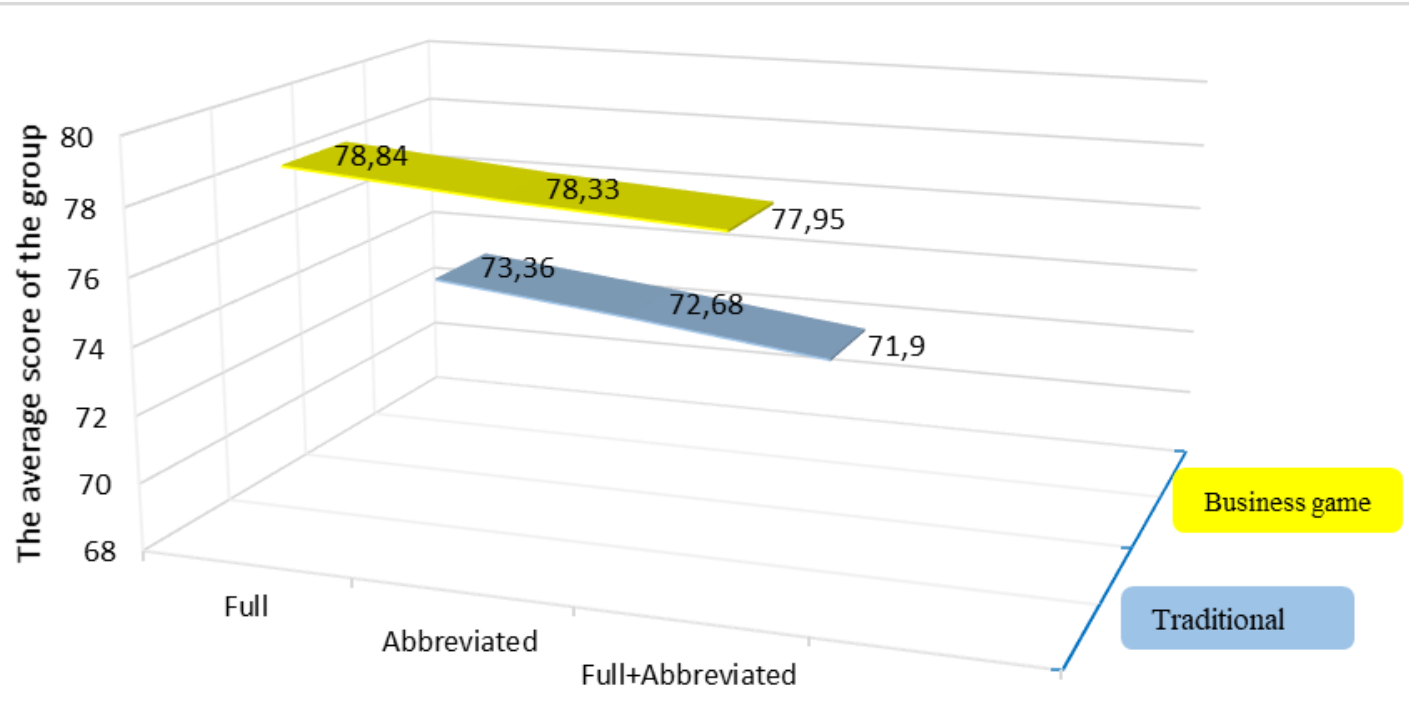

Term of study of students

Fig. 1. Results of students' certification for the module for different methods of teaching the discipline.

After conducting practical exercises in the form of a business game, the degree of mastering of educational material by students was analyzed in comparison with students of control groups, in which this topic was presented in a lecture form. Form of evaluation of field-gala students in the answers to the test tasks and descriptive questions of the training module. The average response scores for the 100-point system were compared with the results of the assessments in the control groups, taking into account the overall score of the groups in the academic year. 
Statistical analysis of the results of the research was performed using the Microsoft Excel 2003 computer program. The obtained data showed that the level of knowledge of students in the groups, where the practical classes were conducted in the form of business games, was significantly higher than the students of the control groups (Fig. 1). The average score of the responses in the control groups was 72.65 points, and in the experimental groups - 78.37. The standard deviation from the mean is \pm 0.434 and \pm 0.271 , respectively.

To find out how significantly different indicators of one sample of the studied results from the other, as students of the study groups received higher scores than the test ones, the Student's criterion was determined to be 11,198. Measurement accuracy had the highest significance level ( $\mathrm{p}<0.001)$.
Comparing the data of averages of responses from the control module of students on a 100-point system with the total score of groups' success in the academic year, the inverse correlation between the two sets of data was found. The strength of the correlation was -0.34389 , that is, in the range of \pm 0.1 to \pm 0.29 , according to the scale is a weak dependence, as evidenced by the level of significance. The total academic achievement of students from all disciplines in the year in the control groups was higher than the results of the control module on the topic "Organization of workplace certification for working conditions at the enterprise", and, conversely, in one of the study groups, these values were almost equal and still in two, the results of the test module were much higher than the average score (Fig. 2).

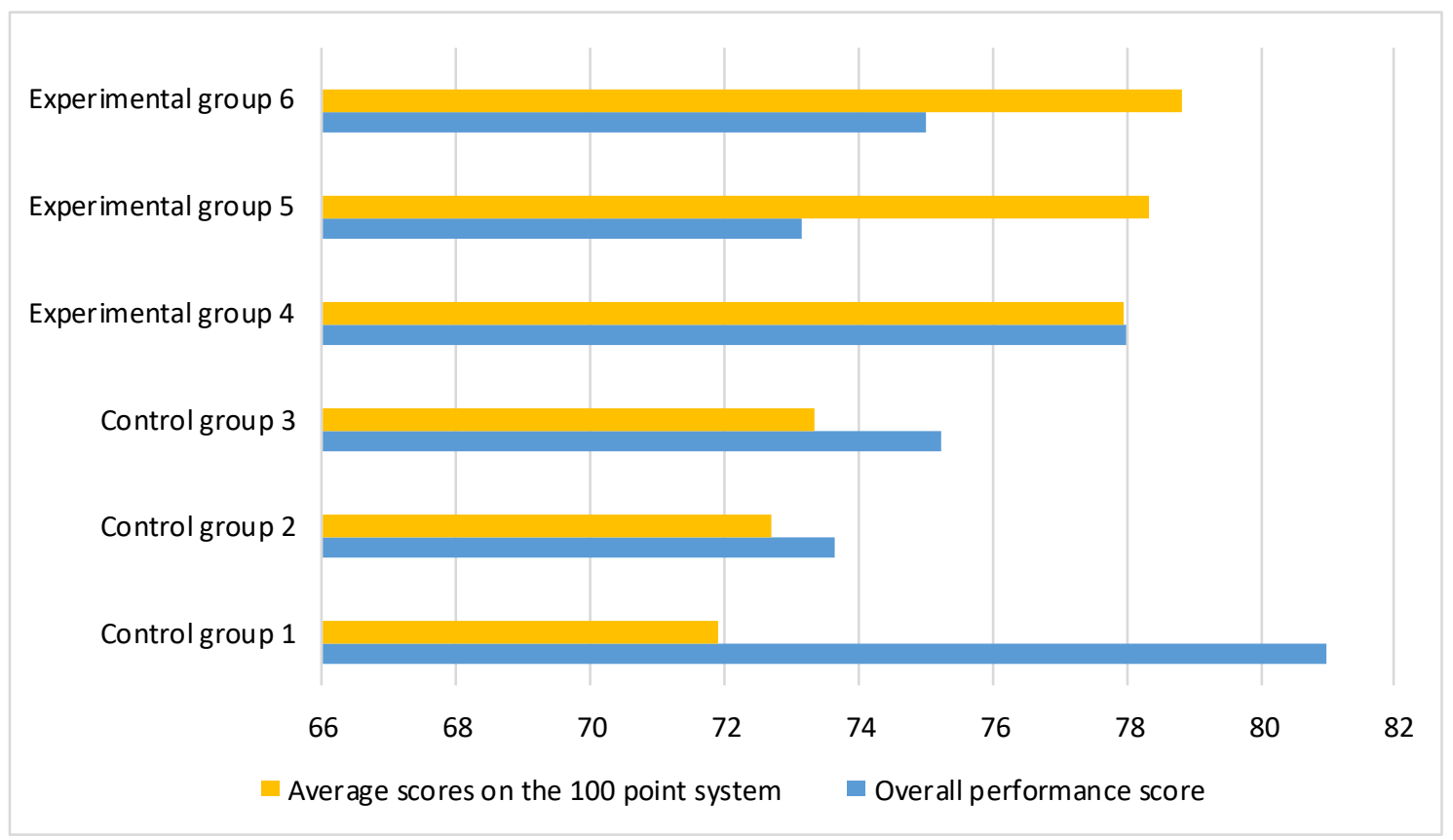

Fig. 2. Comparison of averaged response scores on a 100-point system with the total score of groups for the academic year.

It is established that the use of the developed business game in the educational process has allowed increasing the level of assimilation of material on organizational issues of occupational safety by $8 \%$.

The described method of preparation and conduct of a business game "Organization of performance appraisal of workplaces at the enterprise" can be used as one of the active teaching methods that allow the students to act independently in the simulated situation. The analysis of different ways of solving the situation, actions, methods and ways of coping with critical situations contributes to a significant improvement of the quality of the educational process and the accumulation of experience. Business games in the educational process allow future professionals to form not only certain professional skills but also certain professional and moral personality traits under the conditions of fulfilling their professional duties: efficiency, diligence, honesty, initiative and principle [12].

\section{Conclusions}

1. It is shown that the use of the developed business game "Organization of performance appraisal on working conditions at the enterprise" in the educational process allowed to increase the level of assimilation of material on organizational issues of occupational safety and health by $8 \%$.

2. The described method of preparation and conduct of a business game can be used as one of the active teaching methods, which allow students a certain time to act independently under the conditions of a simulated situation. Analysis of the development of the situation, different ways of solving it, actions, methods and ways of getting out of critical situations contributes to a significant improvement in the quality of the educational process and the accumulation of experience. 


\section{References}

1. Oliynyk N. A. (2018). Teaching Methods of Future Agro-Engineers. Pedagogics of Creating Creative Personality in Higher and General Education Schools: Coll. Sciences. BC. Zaporozhye: KPU, Issue. 60. vol. 2. 134-138.

2. Vasilenko O. V. (2015). Experience of application of modern methods of training in the preparation of specialists of restaurant business in higher educational establishments. Scientific Notes. Series: Problems of Methods of Physical, Mathematical and Technological Education, Issue. 7 (I). 118-121.

3. Dereza O. O., Dereza S. V. (2017). Business Game and its Possibilities in the Professional Training of Future Engineers. Collection of scientific and methodological works: Improvement of the educational process in higher education. No. 20. Melitopol, 100-105.

4. Litvinov A. S. (2017). Pedagogical Provision of Innovations in Education: Educ. manual for the general Sciences. ed. ped. Prof. V.V. Borisova. Sumy. University Book, 265

5. Oliynyk N. Yu. (2015). Efficiency of game models of teaching in the system of modern higher education. Scientific notes. Series: Problems of Methods of Physical, Mathematical and Technological Education, Issue. 7. 7075.

6. Vanyushin V. N., Gvozdikov S. V., Lavrentyev A. R., Orlova L. A. (2015). Businessgame in training: a scientific and practical search. Dzerzhinsk: Kon-Cord Publishing House, 131.

7. Orlova L. A. (2015). Law and Rules of the Game: Monograph, ed. Doctor of Law, prof. V.M. Baranova. Moscow. Yurlitinform Publishing House, 230.

8. Lipkovich I. E., Taran E. A., Orischenko I. V. (2015). Business games: a training tool. Azov-Black Sea Engineering Institute of the State Security Institute of the State Higher State Technical University in Zernograd. Zernograd, 63.

9. Kocherga $O$. (2012). Use of the business game in the process of formation of social responsibility of future primary school teachers. Problems of modern teacher preparation № 6 (Part 3), 49-56.

10. Voynalovich O. (2011). Modern approaches to the organization of intensive training in labor safety. Collection of scientific papers of the 10th international scientific and technical conference "Safety of life and activity people - education, science, practice", Kyiv. Center for Educational Literature, Vol. 1. 116-121.

11. Sekacheva L. M. (2012). Innovations in training occupational safety: problems of introduction. Modern problems of science and education. № 2. 105-112.

12. Yatsuh O. V. (2018). Application of the newest teaching aids and problems of their introduction during the professional training of masters in civil security. AllUkrainian Scientific-Practical Magazine "Headmaster, Lyceum, Gymnasium". Special Topic Issue "Higher Education of Ukraine in the Context of Integration into the European Educational Space”. №6. Book. 2. Volume III (81). Kyiv. Gnosis, 382-392.

13. Voinalovych Oleksandr, Hnatiuk Oleg, Rogovskii Ivan, Pokutnii Oleksandr. (2019). Probability of traumatic situations in mechanized processes in agriculture using mathematical apparatus of Markov chain method. Proceedings of 18th International Scientific Conference "Engineering for rural development". Jelgava, Latvia, May 22-25, Latvia University of Agriculture. Faculty of Engineering. Vol. 18, pp. 563-269. DOI: 10.22616/ERDev2019.18.N245. Scopus.

\section{Список літератури}

1. Oliynyk N. A. Teaching Methods of Future AgroEngineers. Pedagogics of Creating Creative Personality in Higher and General Education Schools: Coll. Sciences. BC. Zaporozhye: KPU, 2018. Issue. 60. vol. 2. 134-138.

2. Vasilenko $O$. V. Experience of application of modern methods of training in the preparation of specialists of restaurant business in higher educational establishments. Scientific Notes. Series: Problems of Methods of Physical, Mathematical and Technological Education, 2015. Issue. 7 (I). pp. 118-121.

3. Dereza O. O., Dereza S. V. Business Game and its Possibilities in the Professional Training of Future Engineers. Collection of scientific and methodological works: Improvement of the educational process in higher education. No. 20. Melitopol, 2017. P. 100-105.

4. Litvinov A. S. Pedagogical Provision of Innovations in Education: Educ. manual for the general Sciences. ed. ped. Prof. V.V. Borisova. Sumy. University Book, 2017. $265 \mathrm{p}$

5. Oliynyk N. Yu. Efficiency of game models of teaching in the system of modern higher education. Scientific notes. Series: Problems of Methods of Physical, Mathematical and Technological Education, 2015. Issue. 7. pp. 70-75.

6. Vanyushin V. N., Gvozdikov S. V., Lavrentyev A. R., Orlova L. A. Businessgame in training: a scientific and practical search. Dzerzhinsk: Kon-Cord Publishing House, 2015. $131 \mathrm{p}$.

7. Orlova L. A. Law and Rules of the Game: Monograph, ed. Doctor of Law, prof. V.M. Baranova. Moscow. Yurlitinform Publishing House, 2015. 230 p.

8. Lipkovich I. E., Taran E. A., Orischenko I. V. Business games: a training tool. Azov-Black Sea Engineering Institute of the State Security Institute of the State Higher State Technical University in Zernograd. Zernograd, 2015. $63 \mathrm{p}$.

9. Kocherga $O$. Use of the business game in the process of formation of social responsibility of future primary school teachers. Problems of modern teacher preparation № 6 (Part 3), 2012. P. 49-56.

10. Voynalovich $O$. Modern approaches to the organization of intensive training in labor safety. Collection of scientific papers of the 10th international scientific and technical conference "Safety of life and activity people education, science, practice", Kyiv. Center for Educational Literature, 2011. Vol. 1. P. 116-121.

11. Sekacheva L. M. Innovations in training occupational safety: problems of introduction. Modern problems of science and education. 2012. № 2. P. 105-112.

12. Yatsuh O. V. Application of the newest teaching aids and problems of their introduction during the professional training of masters in civil security. All-Ukrainian Scientific-Practical Magazine "Headmaster, Lyceum, 
Gymnasium". Special Topic Issue "Higher Education of Ukraine in the Context of Integration into the European Educational Space”. №6. Book. 2. Volume III (81). Kyiv. Gnosis, 2018. P. 382-392.

13. Voinalovych Oleksandr, Hnatiuk Oleg, Rogovskii Ivan, Pokutnii Oleksandr. Probability of traumatic situations in mechanized processes in agriculture using mathematical apparatus of Markov chain method. Proceedings of 18th International Scientific Conference "Engineering for rural development". Jelgava, Latvia, May 22-25, 2019, Latvia University of Agriculture. Faculty of Engineering. Vol. 18, pp. 563-269. DOI: 10.22616/ERDev2019.18.N245. Scopus.

\section{ДІЛОВІ ІГРИ 3 ОХОРОНИ ПРАЦ ЯК ЕФЕКТИВНИЙ ІНСТРУМЕНТ ДЛЯ ПОЛІПШЕННЯ ЗНАНЬ НА РОБОЧОМУ МІСЦІ МАЙБУТНІХ ІНЖЕНЕРІВ СІЛЬСЬКОГОСПОДАРСЬКОГО ВИРОБНИЦТВА \\ О. В. Войналович, С. М. Голопура}

Анотація. Стаття присвячена теоретичному i практичному аналізу використання методу ділової гри у професійній підготовці інженерів сільськогосподарського виробництва. Відзначається, що проблема використання Гри в системі соціально-педагогічної роботи широко представлені в плані педагогіки в цілому дослідження. У той же час ми бачимо дефіцит вітчизняних досліджень, присвячених розробці теоретичних основ і вдосконалення практики використання ділових ігор як активного методу навчання майбутніх інженерів сільськогосподарського виробництва. Специфіка ігрової діяльності визначено, що в напрямку превентивної, профілактичної спрямованості гри як засобу організації змістовного підготовки майбутніх фахівців.

Мета дослідження-розробити, науково обгрунтувати та експериментально апробувати методику ділової гри "організація атестації за умовами праці на підприємстві", спрямована на ознайомлення учнів 3 порядком оцінки ступеня шкоди на виробництві сільськогосподарської продукції. Результатом таких ігор можуть бути як прямі, розвитку особистісних якостей і демонстрації практичної підготовки інженерів сільськогосподарських досліджень. Грати в певних ситуаціях, з залученням учасників гри в ситуацію вибору-це реальний шлях розвитку творчої особистості, а саме такі його якості, як творчий інтерес, допитливість, бажання пізнати себе, впевненість у собі, творчий оптимізм.

В даній роботі, ступінь засвоєння навчального матеріалу студентами після проведення практичних занять у формі ділової гри аналізується в порівнянні зі студентами контрольних груп, в яких ця тема була представлена в формі лекцій. Форми оцінки студент повинен був відповісти на тестові завдання та описові питання модуля. Середній бал за 100-бальною системою відповіді були зіставлені з результатами контролю у контрольних групах, враховуючи загальний результат групи у навчальному році.

Ключові слова: ділова гра, безпека та гігієна праці, кваліфікаційні атестації за умовами праці, виробничої ситуації, ступінь засвоєння навчального матеріалу.

ДЕЛОВЫЕ ИГРЫ ПО ОХРАНЕ ТРУДА КАК ЭФФЕКТИВНЫЙ ИНСТРУМЕНТ ДЛЯ УЛУЧШЕНИЯ ЗНАНИЙ НА РАБОЧЕМ МЕСТЕ БУДУЩИХ ИНЖЕНЕРОВ СЕЛЬСКОХОЗЯЙСТВЕННОГО ПРОИЗВОДСТВА

\section{А. В. Войналович, С. Н. Голопура}

Аннотация. Статья посвящена теоретическому и практическому анализу использования метода деловой игры в профессиональной подготовке инженеров сельскохозяйственного производства. Отмечается, что проблема использования Игры в системе социальнопедагогической работы широко представлены в плане педагогики в целом исследования. В то же время мы видим дефицит отечественных исследований, посвященных разработке теоретических основ и совершенствование практики использования деловых игр как активного метода обучения будущих инженеров сельскохозяйственного производства. Специфика игровой деятельности определено, что в направлении превентивной, профилактической направленности игры как способа организации содержательной подготовки будущих специалистов.

Цель исследования-разработать, научно обосновать и экспериментально апробировать методику деловой игры “организация аттестации по условиям труда на предприятии”, направленная на ознакомление учащихся с порядком оценки степени вреда на производстве сельскохозяйственной продукции. Результатом таких игр могут быть как прямые, развития личностных качеств и демонстрации практической подготовки инженеров сельскохозяйственных исследований. Играть в определенных ситуациях, с привлечением участников игры в ситуацию выбора-это реальный путь развития творческой личности, а именно такие его качества, как творческий интерес, любознательность, желание познать себя, уверенность в себе, творческий оптимизм.

В данной работе, степень усвоения учебного материала студентами после проведения практических занятий в форме деловой игры анализируется в сравнении со студентами контрольных групп, в которых эта тема была представлена в форме лекций. Формы оценки студент должен был ответить на тестовые задания и описательные вопросы модуля. Средний балл по 100-балльной системе ответы были сопоставлены с результатами контроля в контрольных группах, учитывая общий результат группы в учебном году.

Ключевые слова: деловая игра, безопасность и гигиена труда, квалификационные аттестации по условиям труда, производственной ситуации, степень усвоения учебного материала.

O. V. Voinalovych ORCID 0000-0002-9321-2672.

S. M. Holopura ORCID 0000-0001-9531-5344. 